\title{
Higher Order Thinking Skills (HOTS ) Ability of Student High School, College, and Physics Teacher on Physics Lesson Materials
}

\author{
Iwan Permana Suwarna ${ }^{a}$, Yenny Handayani ${ }^{b}$, Neni Ratnasaric

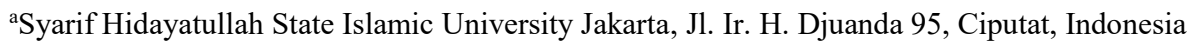 \\ bMadrasah Pembangunan UIN Jakarta, Ciputat, Indonesia \\ ${ }^{\mathrm{c}}$ SMA Negeri 1 Margaasih, Bandung, Indonesia \\ Corresponding e-mail: iwan.permana.suwarna@uinjkt.ac.id
}

\begin{abstract}
Higher order thinking skill (HOTs) is an important skill that must be possessed in the 21 st century. Teachers, students' teacher, and students must have this skill. This study is aimed to describe of HOTs in high school students, physics students' teacher, and physics teachers. The study was conducted on 25 teachers, 40 student teacher, and 25 students (K11), whom selected randomly in Southern Tangerang, Banten, Indonesia. Instruments used in the form of computer based test (CBT) with content validity index $(\mathrm{CVI})=0,86$, validity $(0,87)$, reliability $(0,75)$, difficulty level $(0,5)$, practicality $(87,1 \%)$, and effectiveness $(94,63 \%)$, to measure HOTs. The research method is descriptive. The results: students (K11) have a higher ability than students' teacher and teachers. Students (K11) have good abilities in: creating, evaluating, and synthesis. They have good ability in inferring, justifying, classification, and explaining, while the teacher is good at applying concept and predict. Overall the HOTs skill of teachers, are lower than students' teacher, and students in: inferring, classification, explaining, evaluating, and synthesis. The lowest skill of the three respondents is creating (18\%); and the highest is explaining $(70 \%)$.
\end{abstract}

Keywords: cooperative learning methods, logical thinking, enhancement learning outcomes, elementary students

\section{INTRODUCTION}

Higher order thinking skills (HOTs) are important competencies to be had in life, both in the work environment and in society especially in the 21 st century (Darling-Hammond, L., Adamson, F, 2013). The competencies needed for the 21 st century consist of the skill to: think critical, creative, communicative and collaborative. These competencies are called higher order thinking skills (Kemdikbud, 2016).

Higher order thinking occurs when a person takes new information, and the information is saved in memory and it is interconnected and rearranged and extended to reach a goal or find a possible answer in a confusing situation. The indicators for measuring higher order thinking skills, including: analyzing, evaluating and creating (Krathworl, 2002).

In theory, physics teachers should have higher HOTs ability than students' teacher, and students
(K11). Physics teachers have had a longer learning experience than student teacher, therefor they should have higher and better higher order thinking skills. With good HOTs ability, physics teacher can teach students in good thinking patterns. So, their physics concept understanding will be good too.

How is the condition of higher order thinking skills of high school students, students' teacher, and physics teachers in current, especially, in South Tangerang, Indonesia?

This research will provide information related to the ability of students' HOTs (K11), students' teacher, and physics teachers for researchers, school, physics department or ministry. How is the follow up? 


\section{METHODS}

This research uses descriptive method. The object of this research are; 25 high school students, 40 college students in physics programs (students' teacher), and 25 physics teachers at Southern Tangerang, Indonesia. Data collection techniques used in this study is a test. The respondents are asked to answer a set of higher order thinking skill test in term of computer based test (CBT).

The CBT instrument of this study is an instrument to measure higher order thinking skill in the Physics Education Department (Suwarna, 2016). The CBT instrument has a level of eligibility of 0.87 (very appropriate), with a value of CVI (content validity index $)=0.86$. Instrument validity is 0.87 (very appropriate), reliability 0.75 (High) and level of difficulty 0.50 (medium level), Instrument effectiveness $94.63 \%$ (very effective), $87.1 \%$ (Suwarna, 2016).

The data obtained quantitative data. Quantitative data obtained from respondents' answers to multiple choice HOTS instruments in physics lesson material. Quantitative data is analyzed with descriptive statistics as it is presented in chart.

\section{RESULTS AND DISCUSSION}

Respondents are high school students at 11th grade (K11), students collage of physics department at 8th semester (physics students' teacher), and high school physics teacher (teaching experience more than 5 years) at Southern Tangerang, Banten, Indonesia. All respondents have filled the HOTs instrument's which consists of 28 questions. HOTs instruments used consist of; inferring, justifying, creating, applying, grouping/classifying, explaining, concluding, predicting and synthesizing. The Physics lesson material consist of; 4 questions of fluid, 2 questions of wave, 2 questions of astronomy and earth science, 7 questions of electricity, 8 questions of mechanics, 2 questions of optics, and 3 questions of thermodynamics.

\subsection{HOTS Ability of All Three Respondents}

The total results of data analysis showed the ability of students (K11) higher than student teacher, and physics teachers in answering HOTs questions in physics.

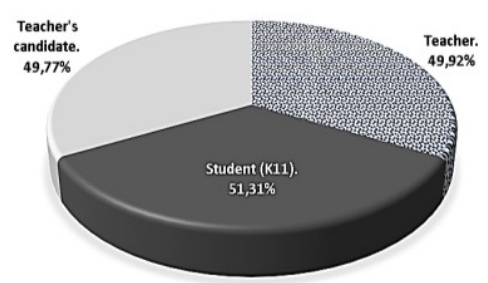

Figur 1. Percentage ability of student (K11), teacher's candidate, and physics teacher in answer HOTs questions.

\subsubsection{HOTs ability of Teachers}

The ability of physics teachers to answer HOTs questions on physics materials show on figure 2 .

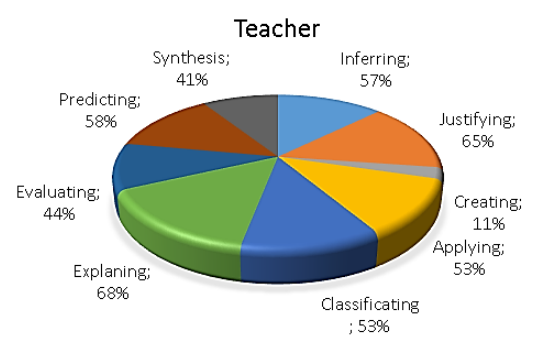

Figure 2. Percentage of physics teacher competence on the HOTS indicator

The lowest physics teachers' ability is creating, and the highest is explaining. Physics teachers have better ability in explaining the physical theories in relation to contemporary phenomena in everyday life $(68 \%)$.

The create competencies is the weakest ability of the teacher. The teacher have difficulties in finding a combination of electronic equipment that can save energy in the first month, previously displayed some electrical equipment with each of its specifications

\subsubsection{HOTs ability of Students (K11)}

The details competencies of students (K11) on HOTs show on figure 3 .

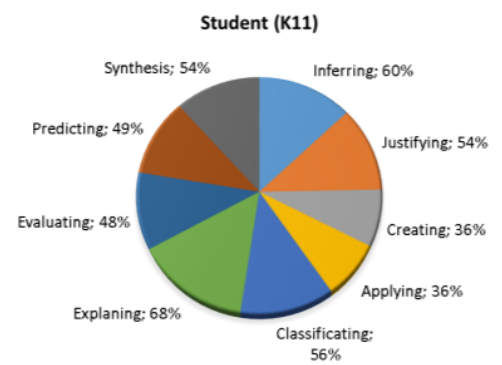

Figure 3. Percentage of students (K11) competence on the HOTS indicators.

As shown in figure 3 the highest ability of the students (K11) is explaining (68\%). Physics teacher 
and students (K11) have equal competence in explaining the physics theories of everyday life phenomenon (68\%). Students (K11) have low competencies on creating and applying physics concept to a certain everyday life phenomenon (36\%). The students (K11)' competence in creating is higher than the physics teachers' ability. In some cases, the way of how students' thinking can be more rational than the teacher does. Teacher often prefers her ego to win.

\subsubsection{HOTs ability of Students' Teacher}

The details competencies of student teacher on HOTs show on figure 4 .

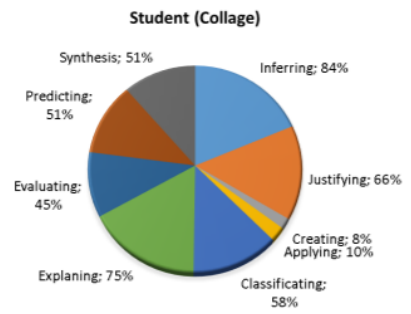

Figure 4 The percentage of students teacher competence on HOTs indicators.

The lowest student teachers' competence is creating $(8 \%)$, and the highest is inferring. Students teacher are more skilled to infer physics in everyday life phenomenon (84\%). In the creating indicator, student teacher skills are higher than physics teachers and students (K11). Another weak capability is on applying the concept. Student teachers are poorly trained in applying the concept of physics in everyday life.

Students are more skilled in making hypotheses of physics phenomena, making predictions about an event that has not happened, giving opinions and arguing on the physic daily life phenomenon.

\subsection{Comparison the ability of the three respondents in each HOTs indicator}

The comparison of the ability of physics teachers, students (K11), and student teacher on each HOTs indicator in detail is shown in the following figure 5 .

The highest ability of HOTs is the inferring ability of student teacher (84\%), and the lowest is the students' (K11) writing ability (8\%). In addition, students have difficulty in applying concepts in their real life to determine the center of mass. Students cannot determine the coordinate of the fall of an airplane on the map, before the plane explodes.

Students (K11) have good abilities in: creating, evaluating and synthesizing. Students have good ability in inferring, justifying, classification, explaining, while the teachers are good at applying concept and predicting. Overall the HOTs ability of teachers, lower than student teacher's, and students' in: inferring, classification, explaining, evaluating, and synthesizing. The lowest ability of the three respondents is creating (18\%); and the highest is explaining $(70 \%)$.

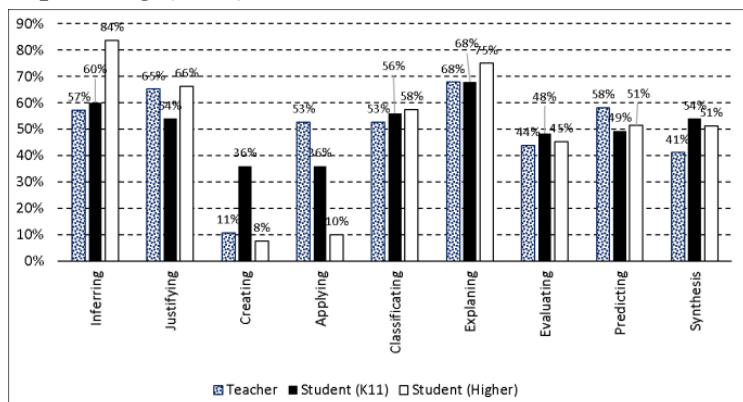

Figure 5. Percentage of the physics teacher, students (K11), and student teacher competencies on HOTS indicator

\subsection{The Average Ability of the Three Respondents in each HOTs Indicator}

The average HOTs ability of the three respondents is shown Figure 6.

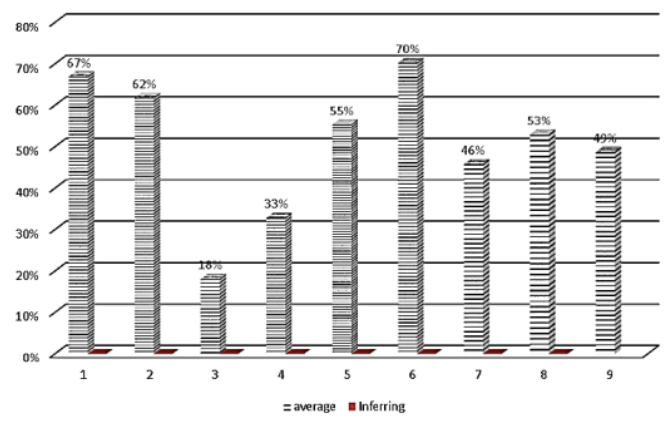

Figure 6. Percentage of students' teacher competencies on HOTS indicator

Explanation: 1. Inferring; 2. Justifying; 3. Creating; 4. Applying; 5. Classification; 6. Explaining; 7. Evaluating; 8. Predicting; 9. Synthesizing

The lowest ability of the three respondents is creating (18\%); and the highest is explaining (70\%). Students (K11), student teacher and physics teachers have a good ability to explain the phenomenon of physics. They can explain the function of a tool based on energy conservation principles.

From the above findings, researchers argue that the low ability of teachers HOTs due to traditional educational process experienced by the teachers in the past

The weaknesses of traditional program models that are collections of largely unrelated courses reinforce this low regard. Three critical components 
of such programs include tight coherence and integration among courses and between course work and clinical work in schools, extensive and intensely supervised clinical work integrated with course work using pedagogies that link theory and practice, and closer, proactive relationships with schools that serve diverse learners effectively and develop and model good teaching. (Darling-Hammond, L., 2006)).

One of the efforts that can be done by teachers and lecturers to improve students' $21^{\text {st }}$ century skill is through student's center learning activity. The appropriate approach that can be applied in the learning process is Project-Based Learning (PBL) (Suwarna, 2017). PBL is an innovative approach to learning that teaches a multitude of critical strategies for success in the twenty-first century. Students drive their own learning through inquiry, as well as working collaboratively to do research and create projects that reflect their knowledge. From gleaning new, viable technology skills, to becoming proficient communicators and advanced problem solvers, students benefit from this approach to instruction (Bell, S., 2010).

\section{CONCLUSIONS}

Based on the analysis and discussion, it can be concluded that:

1. Students (K11) have good abilities in: creating, evaluating and, synthesizing. Students have good ability in inferring, justifying, classification, explaining, while the teacher is good at applying concept and predicting. Overall the HOTs ability of teachers, lower than student teacher, and students in: inferring, classification, explaining, evaluating, and synthesizing. The lowest ability of the three respondents is creating $(18 \%)$; and the highest is explaining $(70 \%)$.

2. The lowest ability of the three respondents is creating (18\%); and the highest is explaining $(70 \%)$.

3. It is suggested to physics lecturers to give student teachers plenty of time to practice applying concepts to real physics problems in the daily life.

4. Teachers must increase their HOTs ability. Thus, the transfer of physics concepts will be more easily done to the students.

5. Governments through the ministry of education and culture should be more often conduct trainings to improve the teacher's competencies especially in their HOTs skills.

\section{REFERENCES}

Bell, S. (2010). Project-based learning for the 21st century: Skills for the future. The Clearing House, 83(2), 39-43.

Darling-Hammond L. Adamson F. (2013). Developing assessments of deeper learning: The costs and benefits of using tests that help students learn. Stanford CA: Stanford University Stanford Center for Opportunity Policy in Education.

Darling-Hammond, L. (2/006). Constructing 21st-century teacher education. Journal of teacher education, 57(3), 300-314.

Kementerian Pendidikan dan Kebudayaan. (2016). Materi Pelatihan Guru Implementasi Kurikulum 2013 Tahun 2016. Sekolah Menengah Atas Materi Teknik Penulisan Soal Berpikir Orde Lebih Tinggi/Higher Order Thinking(Hot). Kementerian Pendidikan dan Kebudayaan. Jakarta.

Suwarna, I. P.. (2017). Mengembangkan instrumen ujian komprehensif pada program studi pendidikan fisika melalui computer based test (CBT). Prosiding Seminar Nasional Profesionalisme Guru di Era Digital 1 (FITK Press), 167

Suwarna, I. P. (2016). Laporan Penelitian Pengembangan Tata Kelola Kelembagaan "Pengembangan Instrumen Ujian Komprehensif Mahasiswa Melalui Computer Based Test pada Program Studi Pendidikan Fisika". Pusat Penelitian dan Penerbitan (PUSLITPEN) LP2M UIN Syarif Hidayatullah Jakarta 